\title{
Human Resource Procurement in Pesantren? Insight from Pesantren Sirojuth Tholibin
}

\author{
Baqiyatush Sholihah \\ Walisongo State Islamic University \\ baqiyatush_sholihah@walisongo.ac.id
}

Article
History:
Submitted:

26-09-2020

Accepted: 08-04-2021

Published: 01-07-2021

\begin{abstract}
:
Human resource procurement is one of the essential stages of organizational decision-making. The scope of procurement consists of planning, recruitment, selection, placement, and orientation of new personnel. Human resources studied in this research are situated in Pesantren comprising of the committee or board; teachers of kitab kuning (classical Arabic Islamic textbook) either with sorogan or bandongan methods; teachers of reciting and memorizing Al-Qur'an; persons in charge of media such as website, Facebook, Twitter, Instagram, YouTube, magazines, and newsletters of Sirojuth Tholibin both. Sirojuth Tholibin commonly used a bottom-up approach in human resources planning. As a part of the planning process, The institution usually combines unstructured interview and observation methods in job analysis. In recruitment and selection, Sirojuth Tholibin pays more attention to behavioral competencies over technical competencies. Recruitment of committee and teachers usually carried out through the employee referral method. Those recruited and selected are recommendations from previous administrators who understand the background of potential candidates. The placement of new human resources is made based on their respective competencies. Orientation is the responsibility of each department, and the duration is according to the speed of each new individual in capturing new knowledge related to their jobs. The weakness of human resources procurement in Sirojuth Tholibin has no formal written job description and job specification. There is also a lack of management information systems of human resource procurement.
\end{abstract}

Keywords: : Pesantren, Procurement, Human Resource Management (HRM) 


\section{Introduction}

Human resources are the most valuable asset in an organization. They are the main drivers for other resources such as material, machine, minute, money, and method within any organization. According to Shaun Tyson, human is crucially important. Work and its management are human activities driven, implemented, supervised, monitored, and assessed by people who interact continuously. ${ }^{1} \quad$ Because human resources are mobilizers, they must have expertise and skills that align with the organization's needs. For this reason, human resources management needs to be done well by any organization that wants to continue to live the life of the organization and realize its goals. This rule applies to all organizations, either profit or non-profit, such as educational institutions, including Pondok pesantren.

Pesantren has a significant role in developing national

1 Shaun Tyson, 2006, Essentials of Human Resource Management, fifth edition, USA: Elsevier, p. 1 education from the colonial period until the independence period. Therefore, in-depth studies primarily related to pesantren management are needed to improve the quality of pesantren. It is crucial to study many aspects of pesantren and manage the pesantren's human resources. The success of pesantren to survive and develop consistently is very much influenced by its human resources. Thus, studying about how pesantren can live long and develop is very important. One of pesantrens that can survive and establish continuously is Pondok Pesantren Sirojuth Tholibin. The age of this pesantren has reached 80 years in 2021 .

Pondok

Pesantren Sirojuth Tholibin is one of the big pesantrens in Central Java. This pesantren was founded in 1941 by AlMaghfurlah Kyai Syamsuri Dahlan $^{2}$ and continued by K.H. Drs. Ahmad Baedlowie Syamsuri, Lc.H. and his younger brother, K.H. Muhammad Anshor Syamsuri. Kiai Anshor passed

2https://sirojuththolibin.net/profil-pondokpesantren-sirojuth-tholibin/ 
away before Kiai Baidhowi. After Kiai Baidhowi passed away, the leadership of the pesantren held by K.H. Baidhowi's wife, Nyai $\mathrm{Hj}$. Maemunah Al-Hafidzah. ${ }^{3}$ She is helped by his first son, K.H. Shofy Al Mubarok Baedlowie Al-Hafidz in managing pesantren.

Sirojuth Tholibin has about 3233 santri in 2020. The pesantren's organizational structure contains nearly 200 people. Besides, there are hundreds of pesantren teachers (asātìdh and ustādhāt $t^{4}$. This number does not include the human resources of formal institutions (MTs and MA), madrasah diniyyah, madrasah takhossus, and madrasah muhadloroh. ${ }^{5}$

Human

resource management (HRM) has some functions: procurement,

3 Al-Hafidz (for male) or AlHafidzoh (for female), abbreviated as $\mathrm{AH}$, is common term in Indonesia. With international transliteration it is written as Al-Häfiz or Al-Hāfizah. The meaning is a person who has memorized 30 juz of Al-Qur'an.

${ }^{4}$ In Indonesia , usually written as asatidz (plural form of ustadz) and ustadzat (plural form of ustadzah)

5 Muhādarah in international transliteration. development, compensation, integration, maintenance, and separation. ${ }^{6}$ This research focused on the first function due to urgency as a gate of all other HRM functions. This research incorporates the qualitative descriptive method. The aim is to gain comprehensive and depth representation related to human resources procurement, its strengths and weaknesses, and ways to improve the procurement in Sirojuth Tholibin.

\section{Review of Literature}

\section{Pesantren}

Pesantren is the oldest educational institution in Indonesia. Pesantren usually built by kiai along with the community. Pesantren is an educational institution that is generally devoted to deepening Islamic religious knowledge. This institution led by a Kiai and has santri or students who live in the boarding. Sometimes pesantren is visited by students who do not stay in the boarding. They come to

6 Taufiqurokhman, Mengenal Sumber Daya Manusia, (Fakultas Ilmu Sosial dan Politik Universitas Prof. Dr. Moestopo Beragama, 2009), p. 43 
study and back home when the learning activity is over and come again when there is a learning schedule. This kind of santri is usually called santri kalong, santri nglajo or nglaju. ${ }^{7}$ Even santri who stay, learn, eat and sleep in the boarding are called santri mukim ${ }^{8}$ or muqim 9 .

Pondok

pesantren established to carry out

7 Nglajo or nglaju is a Javanese language. A word in Indonesian that has a similar meaning to nglaju is melaju (a verb from the basic word laju), which means traveling back and forth from one city to another in one day regularly. (Kamus Besar bahasa Indonesia/KBBI Edisi V, Badan Pengembangan Bahasa dan perbukuan, Kementerian Pendidikan dan Kebudayaan Repiblik Indonesia, 2016-2020 (an android application). Santri nglaju not only a term for santri from other cities but for everyone who comes to study in pesantren but does not stay in boarding, no matter wherever they come from, even though they come from the same village.

8https://pontren.com/2019/05 /09/mari-mengenal-santri-kalong/;

Hasbullah, Sejarah Pendidikan Islam di Indonesia, ( Jakarta: Raja Grafindo Persada, 1999), p. 143 in Zuhimma, Dinamika Perkembangan Pondok Pesantren di Indonesia, Jurnal Darul 'Ilmi Vol. 01, No. 02, 2013, p. 171

9 From Arabic word muqim, means residing or staying ( $A l$ $M a$ 'any Injilizy 'Arabi, Arabic-English Dictionary) education for specific purposes. According to Kiai Ali Ma'shum, pesantren aims to produce ulama. ${ }^{10}$ To Mastuhu, pesantren aims to produce students who have wisdom according to Islam, guided freedom, independence, a high sense of community, ability to manage themselves, respect parents and teachers, love knowledge, and love simplicity. ${ }^{11}$

There are five kinds of pesantren. The first is the simplest pesantren; it is pesantren in the form of a mosque which is used as a place for study the Qur'an. The second is pesantren with basic forms. This pesantren is completed with a dormitory as a residence for students. Third, pesantren with elemental components as classical pesantren but equipped with madrasah with the official curriculum from the government. Fourth, pesantren with components of the previous pesantren

10 Mujamil Qomar, Pesantren; dari Transformasi Metodoloi Menuju Demokratisasi Institusi, Jakarta: Penerbit Erlangga, p. 4

11 Kompri, Manajemen dan Kepemimpinan Pondok Pesantren, 2016, Jakarta: Prenadamedia Grup, p. 4 
model but completed with education in applied skills such as sewing, carpentry, farming, etc. The fifth is modern pesantren, namely pesantren with previous components and completed with general schools from elementary to tertiary education. ${ }^{12}$ Pesantren could also be classified into pesantren salafy (traditional), khalafy (modern), and combination. It inspired the emergence of any kinds of educational institutions.

Pesantren has a big number in Indonesia. Data from Pendis (Pendidikan Islam or Islamic Education) Kemenag (Ministry of Religion) 2011 showed that a number of pesantren in Indonesia is $27.218 .49 .4 \%$ or 13,446 are salafiyah, $11.3 \%$ or 3,064 are khalafiyah, and 39.3\% or 10,708 is combination between salafiyah and khalafiyah. Even the number of santri is $3.642 .738,48 \%$ or 1.747.158 is female santri and $52 \%$ or 1.895 .580 is male. The number of male teaching staff

12 Abdullah Qodir, Manajemen Sumber Daya Manusia di Pondok Pesantren Alfalah Bakalan Kecamatan Kalinyamatan Kabupaten Jepara, JMP Volume 1 nomor 2, December 2012 in pesantren is $65.3 \%$ or 221,783 and $34.7 \%$ or 118,056 are female. ${ }^{13}$ In 2020, Lokadata said that the number of pesantren in Indonesia is 26.967.14 The Minister of Religious Affairs said that the number of pesantren in 2020 reached 28,194 with the number of santri living in the pondok as much as 5 million. "If it is totaled by students who go back and forth to the boarding school as well as TPQ and madrasah, then the number of our students is 18 million people with approximately 1.5 million teaching staff."15 If managed properly, that great number of pesantren and santri will become a formidable capital for the development of Indonesia.

${ }^{13 h t t p: / / p e n d i s . k e m e n a g . g o . i d ~}$ Lfile/dokumen/bukusaku1102.pdf ${ }^{14}$ https://lokadata.beritagar.id /chart/preview/jumlah-pesantrenmenurut-provinsi-2020-1592279374

${ }^{15}$ https://www.hidayatullah.c om/berita/nasional/read/2020/02/ 14/178098/total-18-juta-santri-dan28-ribu-pesantren-di-indonesia.html 
Review of Literature

Procurement in Human

Resources

(HRM)

Human resource is a potential ability that exists in human. This potential consists of the ability to think, communicate, act, having morals, etc. ${ }^{16}$ These potentials need to be explored so that they can appear optimally and be utilized for human life as individuals and society. To explore well, organizations need good HRM.

HRM is the recognition of the importance of an organization's workforce as vital human resources contributing to the goals of the organization, and the utilization of several functions and activities to ensure that they are used effectively and fairly for the benefit of the individual, organization, and society (Schuler, Dowling, Smart dan Huber in Priyono (2010: 4). HRM comprises a set of policies designed to maximize organizational integration,

16 Sedarmayanti, Manajemen Sumber Daya Manusia; Reformasi Birokrasi dan Manajemen Pegawai Negeri Sipil, Cetakan ke-5, (Bandung: Rafika Aditama, 2016), p. 11 employee commitment, flexibility and quality of work. (Guest in Priyono (2010: 5). ${ }^{17}$

Taufiqurokhman classified HRM function into two kinds. They are managerial functions (planning, organizing, directing, controlling) and operational functions (procurement, development, compensation, integration, maintenance, and separation. $^{18}$ Module of Human Resource management said that Edwin Flippo defines HRM as "planning, organizing, directing, controlling of procurement, development, compensation, integration, maintenance and separation of human resources to the end that individual, organizational and social objectives are achieved."19

$\mathrm{d} / \mathrm{wp}$

17https://www.binadarma.ac.i content/uploads/2016/03/NASKA H_MSDM_PDF_LENGKAP.pdf

18 Taufiqurokhman, Mengenal Sumber Daya Manusia, (Fakultas Ilmu Sosial dan Politik Universitas Prof. Dr. Moestopo Beragama, 2009), p. 43

19 Smt. Shyamala. M., Module of Human Resource Management, (University of Calicut, Department of Commerce and Management Studies), p. 6 
Flippo (1980) classified HRM components as procurement, development, compensation, integration, maintenance, and separation. ${ }^{20}$ Procurement consists of human resource planning, recruitment, selection, placement, induction, or orientation of new employees or human resources. ${ }^{21}$

\section{Human Resource Planning}

There is a process called as job analysis in the human resource planning. Job analysis is a "procedure for determining a job's duties and skill requirements and the kind of person who should be hired for it."22 Many figures reveal the meaning of job analysis. Yoder (1959) stated that job analysis is a procedure for finding facts related to each job systematically and recorded.

The information gained through job analysis is work activities, human behaviors, machines, tools, equipment, work aids, performance standards, job context, and human requirements. ${ }^{23}$ Job analysis can be used as a basis in the recruitment process and the basis for developing human resources through the education and training process. 24 Through job analysis, it will be possible to determine if there is a lack of qualifications in a particular job. If so, the follow-up question is whether this qualification deficiency can be met through education and training or whether new personnel recruitment is needed.
20 Yoo Keun Shin, Human Resource Management in Korean Firms and Its Future Outlook, Seoul Nastional University: Seoul Journal of Business, Volume 5, Number 1/5, December 1999

21 Sedarmayanti, Manajemen Sumber Daya Manusia: Reformasi Birokrasi dan Manajemen Pegawai Negeri Sipil, (Bandung: Refika Aditama, 2010) p. 15-16

22 Gary Dessler, Human Resource Management, fifteenth edition, (USA: Pearson, 2013), p. 97
23 Gary Dessler, Human Resource Management, fifteenth edition, (USA: Pearson, 2013), p. 97-98

24 Emron Edison, Yohny Anwar, and Imas Komariyah, Manajemen Sumber Daya Manusia:Strategi dan Perubahan dalam Rangka Meningkatkan Kinerja Pegawai dan Organisasi, (Bandung: Alfabeta, 2018), p. 69 
Human Resources

Recruitment, Selection, Placement, and Orientation

Recruitment is a "process of identifying and attracting potential candidates from within and outside an organization to begin evaluating them for future employment; selection begins when the right caliber of candidates are identified". ${ }^{25}$ The process after recruitment is selection. It is a process of the best candidates to occupy an empty position. Selection can be held through certain tests, assessment centers, and interview. ${ }^{26}$

There are several steps usually used in selection, those are: selection of application letters, filling in the application form, reference checks, preliminary interview, acceptance tests, psychological test, medical

25 Joy O. Ekwoaba, Ugochuckwu. U.U. Ikeije, Ndubuisi Ufoma, The Impact of Recruitment and Selection Criteria on Organizational performance, Global Journal of Human Resource Management, Vol.3, No.2, p.22-33, March 2015

26 Michael Armstrong, A handbook of Human Resource Management Practice, $10^{\text {th }}$ edition, ( London and Philadelphia: Kogan Page, 2006), p. 429 check-up, final direct supervisor interview, and the last is deciding whether to accept or reject. ${ }^{27}$

After the organization determined who are accepted after the selection process, the organization could introduce the responsibility and duties to that selected people to know the organization well and handle their duties and responsibility. This process could be named as induction or orientation. Orientation's aim is to make the people have been selected know their environment and their responsibility well. In the corporate's figure, sometimes there is no term of orientation but there is term of onboarding. It is similar but corporate also adds that onboarding activities can be casual, informal activities such as lunch or playing together in a game.

\section{Research Findings and}

Discussion

Overview of Pondok Pesantren Sirojuth Tholibin This Nahdhatul Ulamabased institution was

27 Priyono, Manajemen Sumber Daya Manusia, (Sidoarjo: Zifatama Publisher, 2010), p. 61-62 
founded by K.H. Syamsuri Dahlan in 1941. In 2013 the pesantren received a Decree of the Ministry of Law and Human Rights No. AHU1847.AH.01.04. This pesantren initially only used traditional salaf method. Over time, it developed rapidly by combining the methods of salaf and khalaf. Sirojuth Tholibin has a program of tahfizul qur'ān, madrasah diniyah, madrasah takhashush madrasah (takhașsus), (muhādarah) and formal madrasah (MTs and MA). Madrasah diniyah, MTs and MA here are under the auspices of the Tajul Ulum Foundation.

Sirojuth Tholibin has 3233 santri in 2020. As such, Sirojuth Tholibin became the largest pesantren in Grobogan district. The second-largest is a pesantren with five hundred santri. The difference of numbers is very high. This shows that the development of the quantity of santri in Sirojuth Tholibin far exceeds other pesantrens in Grobogan district.Based on the classification of pesantren made by Ziemek (1986), Sirojuth Tholibin is part of modern pesantren because it has formal education. In addition, Sirojuth Tholibin is also equipped with practical skills education such as screen printing and sewing.

Based on the pesantren classification by Zamakhsari Dhofier (1994), Sirojuth Tholibin is a combination of the salafi and khalafi pesantren because Sirojuth Tholibin intensively provides Islamic religious learning by reciting kitab kuning. ${ }^{28}$ Additionally, Sirojuth Tholibin also has general education organized through the Tajul Ulum foundation which oversees formal schools, namely MTs Banin and Banat and MA Banin and Banat. Although, according to the Ministrial Decree of the Minister of Religion affairs of the Republic of Indonesia No. 3/1997, Sirojuth Tholibin is a type D pesantren, it is pesantren that provides education with a boarding

28 Called as kitab kuning (yellow book) because usually the classical Islamic Arabic textbooks are printed on yellow papers. Although now some have also been reprinted on white paper, the term yellow book is still attached to refer to classical Islamic textbooks in Indonesian pesantren. 
system as well as a school or madrasah system. ${ }^{29}$

The vision of Sirojuth Tholibin is to be an excellent educational institution to prepare generations who have good moral and can compete in today's world. The mission of Sirojuth Tholibin: organizing education by combining a modern and salaf system based on "al-muhâfazatu 'alā qadimi aș-șälih wa al-akhdhu bi al-jadìdi al-așlah" ; creating generations who have good morality and extensive knowledge; equipping generations with the correct creed and sharia in accordance with the main teachings of Ahlu as-Sunnah wa al-Jamā'ah. So, the purpose of pesantren Sirojuth Tholibin is not only limited to producing ulama'. Like the current era, of the millions of santri, of course, all of them can't become ulama'. In the past when there were few students, it was still possible. Although all of them can't

${ }_{29}$ Classifification of pesantren could be seen in Abdullah Qodir's writing under the title Manajemen Sumber Daya Manusia di Pondok Pesantren Al-Falah Bakalan Kecamatan Kalinyamatan Kabupaten Jepara. become ulama', but the pesantren has a goal for the santri to have characters like ulama'.

\section{Human Resources}

Procurement in Pondok

Pesantren Sirojuth Tholibin

William B Castetter said that "human reources refers to those individuals who comprise the school staff and contribute to the school system's operation." School here means educational organization. Based on such theory, this research discussed about human resources, they are individuals who contribute to Sirojuth Tholibin system as an Islamic educational organization or institution.

Human resources in this paper refer to pengurus (board/committee), mustahiq sorogan $^{30}$ kitab kuning, mustahiq

30 Sorogan is a learning method in pesantren. Santri recite kitab kuning and the teacher listens to them one by one. The teacher will correct if there is an error. This method is intended to determine the ability of students in reading and understanding kitab kuning. Sorogan also used in the learning of reciting Qur'an. In sorogan Qur'an techers just focus on the way of reciting based on ilm tajwid, not about understanding the meaning of 
bandogan kitab kuning, mustahiq al-qur'an, mustahiq musyawarah, asātìdh and ustādhät either in the male or female dormitory, persons in charge of media (website, Facebook, Twitter, Instagram, YouTube, as well as magazines and newsletters of Sirojuth Tholibin).

\section{Human Resource Planning}

Procurement as the first HRM function consists of human resource planning, recruitment, selection, placement, and orientation of new individuals. Planning is an essential part of the management process. Good planning will contribute toward exemplary implementation. Human resource planning is a process in which an organization attempts to estimate the demand for labor and evaluate the size, nature, and sources on the supply which will be reared to meet the demand."31 Planning aimed at determining what kind of people will be recruited, how

verses recited. Sorogan has same meaning with talaqqi in Arabic language.

31 Reilly in Edy Sutrisno, Manajemen Sumber Daya Manusia, (Jakarta: Kencana, 2017), p. 33 people will be recruited, how steps will be taken to manage the people who have been recruited, how to develop them, how to provide compensation and how to dismiss them. Accuracy in planning greatly affects the success of management as a whole.

One of the main activities in human resource planning is job analysis with some results: job description, job specification, and job classification. ${ }^{32}$ Job analysis is a basis in human resources planning. Accuracy in job analysis is the key to the accuracy in planning. Inaccuracy in analyzing will make planning not right on organizational goals.

Job analysis is carried out to collect all information related to a job and obtain job descriptions, requirements, and ideal competencies needed to hold the job. The ideal requirements and competencies must be possessed by human

32 Emron Edison, Yohny Anwar, and Imas Komariyah, Manajemen Sumber Daya Manusia:Strategi dan Perubahan dalam Rangka Meningkatkan Kinerja Pegawai dan Organisasi, (Bandung: Alfabeta, 2018), p. 73 
resources to be recruited and selected. Therefore, job analysis could be used as a basis for recruitment and development program.

The board itself carries out job analysis related to the board positions at Sirojuth Tholibin. The board carried out job analysis following their respective fields. For example, the cleanness section or department analyzed jobs in the field of cleanliness; the secretary analyzed work in the secretarial field, the mass media administrators analyzed jobs in the field of mass media, as well as other fields. The main board stated why the job analysis must be made in advance by each field because they know best, feel overwhelmed by their tasks, or feel whether the people in the department can work well together or not. By listening to them, it is hoped that accurate information will be obtained regarding the workforce's needs so that new personnel or individuals will be appointed as needed.

Job analysis that resulted in description and specifications should have been made in writing, but this is usually not done at Sirojuth
Tholibin. Yoder (1959) said that job analysis is a procedure for finding facts related to each job systematically and recorded. So, the weakness of Sirojuth Tholibin related to it is in the recording aspect.

At Sirojuth Tholibin, job analysis is carried out at least once a year after pengajian khotmil Qur'an ${ }^{33}$ and sometimes added outside of the routine schedule as needed. This is conducted to evaluate how much workload is carried by each person in each field or each department. This is a good strategy in HRM. With this evaluation, the leader will immediately know whether there are overlapping parts of the work, causing decreased productivity. Or is there any personnel whose position is not in accordance with their expertise so that it needs to be done rolling or not, or are there any personnel who already have plans to finish the study in Sirojuth Tholibin so that personnel replacement need to be prepared. In this

33 Pengajian khotmil Qur'an is an annual graduation ceremony for santri who have completed memorizing the 30 juz of Qur'an 
case, the pesantren has good planning because it is carried out in advance, not suddenly so that there is enough time to prepare the right new personnel.

In job analysis, the interview could be unstructured and structured. The structured interview follows a systematic approach where employees are interviewed accurately and consistently, following a preset format. Unstructured interview unravels without a preset structure. The interview process is carried out as a conversation with no specific questions predefined, could be just with "tell me about your job".34 Sirojuth Tholibin usually uses unstructured interviews besides of observation method.

Informally, interviews were carried out by the lurah pondok (head of pesantren) or core committee for each department or section. They asked each section or department to explain their needs related to human resources.

34 Gary Dessler, Human Resource Management, fifteenth edition, (USA: Pearson, 2013), p.
Job analysis pays attention to job changes that arise due to various factors, such as technological developments, changes in organizational design, and changes due to other causes such as study of santri that has almost finished. The number of personnel can change according to the job development. For example, the secretary who used to be only two persons in female boarding is now four persons. The treasurer used to be two people, now there are also four people. As well as in male boarding (pondok putra).

In general, the analysis of the job carried out at the Sirojuth Tholibin has been able to answer the following important questions. According to Mondy, job analysis must answer six critical questions as follows:

1. What kind of mental and physical work will get the job done?

2. When will the work be finished?

3. Where will the work be accomplished?

4. How do workers do the work?

5. Why is the work done? 
6. What qualifications are needed to do the job? 35

Those questions are usually answered in job analysis in Sirojuth Tholibin but without structured written document related. This is one of weaknesses in job analysis. There is no written job description related to the name of job, summary, equipment, environment, and activity as required by the experts. ${ }^{36}$ But verbally the pengurus can explain it. So, the system relies on memory.

Without a clear job description and job specification, humans risk not focusing on what should be done. Without clear job descriptions and job specifications there is also a risk of overlapping at certain points in the organization. It would be better to have a written job description with thousands of students that would make all students know easier. This certainly

35 Yusniar Lubis, etc, Manajemen dan Riset Sumber Daya Manusia, (Bandung: Alfabeta, 2018), p.67-68

36 Taufiqurokhman, Mengenal Sumber Daya Manusia, (Fakultas Ilmu Sosial dan Politik Universitas Prof. Dr. Moestopo Beragama, 2009), p. 53 will make time and energyefficient. The unavailability of written job descriptions and specifications can lead to unclear tasks easily understood by all parties, both the management and the managed students. A written job description accessible to anyone will burden off answering too many questions regarding who is responsible for what.

Noor Arifin, in his book, states that in the planning system, there are four activities. The first is the inventory of human resources, human resource forecasting, preparation of human resource plans, monitoring and evaluation of human resources. Inventory here means the recording or data collection of human resources available in the organization. Forecasting means predicting human resource needs in the future. Human resource planning refers to determining human resource requirements based on forecasting the development, implementation, and control of these needs integrated with organizational planning so that planning can be more precise and economical. 
Finally, the leader of the personnel carries out supervision and evaluation of human resources under him to ensure that planning and implementation runs well. ${ }^{37}$ Sirojuth Tholibin has done these things as described above. Supervision and evaluation in planning lead by lurah pondok under the guidance of ndalem ${ }^{38}$. The weakness in Sirojuth Tholibin either in male or female dormitory related to those processes is just in the matter of structured written data.

\section{Recruitment,}

Selection, Placement, and Orientation in Pondok Putra

Recruitment is important aspect in HRM because it will influence productivity and performance. Therefore, low productivity and bad performance could be caused by bad recruitment system. General recruitment starts from the process of looking for applicants until their applications are submitted. The applications are then

37 Noor Arifin, Manajemen Sumberdaya Manusia; Teori dan Kasus, (Jepara: UNISNU Press), p. 16

38 Ndalem is common term in pesantren world. Ndalem means kiai and family who lead the pesantren. selected or rejected via a selection procedure.

Pondok Pesantren Sirojuth Tholibin Putra (male boarding) has about 70 administrators or boar, 40 teachers $^{39}$ of sorogan kitab kuning, and 30 persons in charge of deliberation meeting (musyawarah). Each division proposes the names to the lurah and the deputy, then they continue by submitting the names to ndalem The names were proposed without confirmation with the name owner. Before names were proposed, each division had monitored the candidate in advance to see how fit the person was to occupy the existing position. The main consideration is activeness, behavior, obey when given a task. This is a consideration so that when they served as pengurus are willing to carry out their duties with full responsibility. Through routine cleaning activities, the committees usually assess the activeness of candidates.

39 In male pondok of Sirojuth Tholibin, teachers of kitab kuning, alqur'an and person in charge of musyawarah called as mustahiq 
There is no stipulation that a santri must have been in boarding school for several years to become a pengurus. However, the senior committee usually assigns easy tasks first to the relatively new santri administrators.

A kind of career path is applied even though it is not patented in a regulation. The board of the new santri usually occupies a position as a library administrator, or in other relatively minor sections. Gradually the management can move up to a management with bigger responsibilities, such as in the education department for example.

The persons who handled sorogan juz amma are the santri. Those who handled (teach and control, called as mustahiq in male boarding) the activities of sorogan alQur'an bin-nadhor (reciting by looking at the al-Qur'an text) are: $\mathrm{KH}$. Maesur Zuhri, AH, KH. Mu'tamir Hilmy Mujtaba, AH, K. Munshorif, AH, K. Ali Syadad, AH, Ust. Shofi'i, AH, Ust. Muslimin, $\mathrm{AH}$, and Ust. Aminuddin, $\mathrm{AH}$.

They were chosen by Gus Shofi. Per person handles about 30 students per day. Santri bin-nadhor and bil-ghoib can also do sorogan Qur'an with kiai outer of Pondok Sirojuth Tholibin such Kiai Rokhwan and Kiai Ahmad Mudhofir (kiai of Pondok Pesantren An-Nashriyah). For the kiai outside Sirojuth Tholibin's complex who did not come to Sirojuth Tholibin to teach like this, Sirojuth Tholibin did not have the authority to regulate it them.

Sirojuth Tholibin always allow male santri to ngaji Qur'an bil-ghoib (memorize Al-Qur'an) outer of Sirojuth Tholibin, studying from a specialist in the Qur'an to memorize the Qur'an because in the past, there was no male student of Sirojuth Tholibin who had memorized the Qur'an, only Ibu Nyai Hj. Maemunah who memorized it. Now even though Gus Shofi as a pengasuh and his younger brother (Gus Hilmi) memorized the whole of Qur'an and took care of male students who memorized the Qur'an, male students were still given the freedom to learn to memorize the Qur'an from kiai around the Sirojuth Tholibin.

The uniqueness of Sirojuth Tholibin is its ability 
to build close relationships with many kiai around the Sirojuth Tholibin, even though the kiai also has his own pondok pesantren. In fact, the recruitment model for the mustahiq Qur'an in Pesantren Sirojuth Tholibin Putra involved Kiai Ahmad Mudlofir, the kiai of Pesantren At-Taufiqiyah. Candidates for mustahiq juz 'amma were previously selected by the huffadz department ${ }^{40}$, and then submitted to the Kiai Mudlofir to be selected. Mustahiq that kiai Dhofir approves then determined to be mustahiq. So, the criteria are students who have been deemed capable by Kiai Mudhofir as an elder of the al-Qur'an teacher in Brabo village, because in the past the mustahiq juz 'amma were senior students who had memorize Qur'an with Kiai Mudhofir. In the past, mustahiq of ngaji bil-ghoib is Kiai Mudhofir, before Gus Shofi got such kind of recommendation to teach ngaji bil-ghoib from Kiai Mudhofir.

40 Huffadz department has responsibility to manage program for santri who memorize Al-Qur'an
Mustahiq ngaji sorogan kitab kuning are taken from santri who have graduated from madrasah muhadhoroh. Alumnus of madrasah muhadhoroh have an obligation to serve for 1 year. Their dedication is to participate in teaching or other educational activities. If there is still a shortage of teachers from alumni of madrasah muhadhoroh, then they will be taken from grade 3 or under third grade students but they are also served as pengurus. The most important requirement to become a mustahiq is to understand the knowledge of nahwu and shorof, Arabic grammar. This qualification is a must.

The ones who teach ngaji bandongan $^{41}$ are Gus Shofi and ustadz of madrasah Muhadhoroh.

The musyawaroh that the students participate in is adjusted to their grade level in the madrasah diniyyah which consists of nine levels. Per class consist of thirty

41 Bandongan or wetonan is a collective learning method in pesantren. Teacher (kiai or ustadz) recites and explains and the students or santri listen and take a note in their own textbook. 
santri. The class leader regulates the turn of the santri to be the moderator in the deliberations. There are 30 santri as mustahiq for handling the musyawaroh or deliberation. They are taken from grades 2-3 of madrasah muhadhoroh class or those who have graduated. This is different from the sorogan handle taken from at least grade 3 .

Unlike those who are included in the management structure, santri who handle the musyawaroh and sorogan (talaqqi) ${ }^{42}$ are usually offered before being appointed, they can choose to accept or refuse.

Orientation in Pesantren Sirojuth Tholibin Putra is carried out by each division. Each of the old board members gave directions to the new ones. They tell them what tasks they have to do as managers (pengurus) and mustahiq. Before that, they were also given directions together with other administrators. They were given an overview of their duties, schedules, how to

42 Sorogan has same meaning with talaqqi. Ahmad Baso, Pesantren Studies 2a (Jakarta: Pustaka Afid, 2012), p. 102 teach and how to educate well.

Recruitment, Selection, and Orientation in Pondok Putri

Recruitment and selection process of new administrators or managers done by the former board. The processes are: the first step, the lurah holds an internal meeting with the core board (head of boarding (lurah pondok), deputy head, secretary and treasurer) regarding the new candidates. The main board then gives instructions to the departments to submit the names of candidates they think are prospective for future board in their respective departments. So, the main board and the sections together prepared names. The names candidates then discussed in a meeting between main board and departments. In this meeting each department present the names and give argumentations related to the reason why do they choose the names. Not all the names are accepted by main board. Sometimes the selected names are from the main board after discussing with the departments. 
Either departments or main board proposes names that they recommend based on their observations. Long before they proposed the names, the sections or departments specifically observed potential santri to be nominated. Usually the members of the cleaning team are selected. The cleaning team apart from this committee numbered approximately twenty people. They usually help administrators in the cleaning department carry out a cleaning competition program between rooms and between complexes assessed by the cleaning department administrator. The potential santri who were in the cleaning team were asked to help the cleaning section to see that their work was good.

Apart from members of the cleaning team, candidates for management were also taken from members of the canteen. Canteen members who are nominated to be managers have no limit on how long they have taken to manage the canteen.

Santri who have more potential who are members of the cleaning team and the canteen team prepared to become a cadre of administrators and teachers in the future. From time to time they are trained by being given responsibility, so that they are finally ready to be given greater responsibility as the main board.

The length of time for observing these candidates for pengurus is not determined how long. To become a candidate, the students are also not determined how long they have to be members of the cleaning team and the canteen team. The number of candidates being proposed is usually 1.5 to twice the amount needed.

At the pondok putri, management always pays attention to chemistry when choosing new human resources to occupy a management position; it is first assessed whether the old management will be suitable and comfortable with the new management who will be working with them in the future or not.

The administrators explained that they usually asked about people's characters through their schoolmates and roommates. So the recruiter listens to 
information from multiple sources and then discusses it in each division. To find candidates in the recruitment process, the administrators follow a general rule that is very popular among santri, it is: "Don't ask something about someone to that person directly, but ask his friend, because actually someone is drawn from his best friend."

After the division got several names, they submitted them to the top officials or the main board members. The main board then brings the names to the appointment meeting. The next process after the main board with the departments decided the selected names is, those names proposed to ndalem. If ndalem party approved the proposed names, the next step could be continued, otherwise it would be canceled and had to look for another name instead. Sometimes ndalem party selects the names of candidates for the management by their selves, not a suggestion from the pengurus.

From above elaboration, it can be seen that there are differences in recruitment for each position. Lurah pondok, both male and female, are chosen directly by the kiai with a direct pointing pattern without being offered after the kiai observes and considers that a person is worthy of being assigned a big responsibility as a manager to help take care of thousands of students. Sometimes, the names of candidates are recommendations from the board.

Pondok putri is more democratic because there is a process of bidding to those who are appointed and giving them the freedom to reject or accept. Although given freedom, only a small proportion refused. In the last six years or so there have only been two people who refused. Even in the pondok putra, only about $6 \%$. The philosophical values greatly influence the pattern of HRM. The beliefs that the students who are willing to devote themselves to help managing the pesantren will always get blessings that make them work without expecting material rewards.

Recruitment and selection of ustadzah of Qur'an (except for juz 'amma) are directly selected by ndalem by taking 
into account their fluency and ketartilan $^{43}$ in reciting and abilities in teaching. Recruitment and selection of ustadzah kitab or others (except Al-Qur'an) are carried out by pengurus.

In Sirbin also there are persons in charge related to multimedia management. Siroujuth Tholibin has Sirbin $\mathrm{TV}$, website, instagram, and facebook. The management of multimedia is not separated between male and female pesantren. Procurement of personnels is handled by the manager from the recruitment, selection, until orientation.

Social media manager's jobs are:

- In charge of and organize field coordinators;

- Manage all posts on social media;

- Send the work of the coordinator to the caregiver for tashih purposes;

43 Ketartilan (from the root word tartil) relates to the tempo of the reciting. The unit of tempo in this context is BPM (beats per minute). Reciting with tartil means reciting at a slow tempo, not in a hurry.
- Selecting content that is appropriate to appear and not.

Writing coordinator duties are:

- Responsible for all works in the field of writing;

- Manage all written works of contributors;

- Editing papers that need improvement;

- Sending papers to social media managers.

Permanent coordinator's jobs are:

- Create original works;

- Submitting works to the respective field coordinators.

Those people selected by general manager of multimedia based on the interest of santri and their ability.

\section{Conclusion}

Sirojuth

Tholibin incorporates a bottom-up approach in planning as a part of the procurement process. Sirojuth Tholibin is unique in recruiting lurah pondok (Pesantren Director). Lurah Pondok Putra (male dormitory director) was recruited directly by ndalem (Kyai's family), commonly 
the candidate was proposed by the previous lurah without notifying the nominated person first. Candidate of lurah for the female dormitory sometimes proposed by ndalem directly and discussed with the board. Male dormitory nomination involves the senior Kiai in the village in recruiting and selecting mustahiq Qur'an. For pondok putri thr authority to select teachers belongs to $\mathrm{Bu}$ Nyai Maemunah.

In recruitment process, Sirojuth Tholibin pays more attention on behavioral competencies over technical competencies. Recruitment of board usually carried out using employee referral method because those recruited are recommendations from previous administrators who have been observed for a certain period to ensure that they are eligible to be elected. There is uniqueness in the recruitment system, especially in recruiting pengurus or manager because almost all of them did not realize before they have been chosen in the position.

The weakness of human resource procurement in
Sirojuth Tholibin is the absence of job description and job specification in either female or male boarding. There is also a weakness in the information system. There was a challenge to find the digital or manual documents related to human resources management.

Another weakness is, there is no clear structure pertaining to persons in charge of media.

\section{Bibliography}
Al-Ma'any Injilizy 'Arabi, Arabic-English
Dictionary

Armstrong. Michael, A handbook of Human Resource Management Practice, 10th edition, ( London and Philadelphia: Kogan Page, 2006)

Baso. Ahmad, Pesantren Studies 2a (Jakarta: Pustaka Afid, 2012)

Dessler. Gary, Human Resource Management, fifteenth edition, (USA: Pearson, 2013)

Edison. Emron, Yohny Anwar, and Imas Komariyah, Manajemen 
Sumber

Manusia:Strategi dan

Perubahan dalam

Rangka Meningkatkan

Kinerja Pegawai dan

Organisasi, (Bandung:

Alfabeta, 2018

Ekwoaba.

Joy

Ugochuckwu.

O., U.U.

Ikeije, Ndubuisi Ufoma,

The Impact

Recruitment of

Selection Criteria on

Organizational

performance, Global

Journal of Human

Resource Management,

Vol.3, No.2, March 2015

http://pendis.kemenag.go.id

/file/dokumen/bukusa

ku1102.pdf

https://lokadata.beritagar.id

/chart/preview/jumlah-

pesantren-menurut-

provinsi-2020-

1592279374

https://pontren.com/2019/0

5/09/mari-mengenal-

santri-kalong/;

https://sirojuth-

tholibin.net/profil-

pondok-pesantren-

sirojuth-tholibin/ d/wp-

content/uploads/2016/0

3/NASKAH_MSDM_PD

F_LENGKAP.pdf

https://www.hidayatullah.co $\mathrm{m} /$ berita/nasional $/ \mathrm{read}$ /2020/02/14/178098/to

tal-18-juta-santri-dan-28ribu-pesantren-diindonesia.html

Kamus Besar bahasa Indonesia/KBBI Edisi V, Badan Pengembangan Bahasa dan perbukuan, Kementerian Pendidikan dan Kebudayaan Repiblik Indonesia, 20162020 (an android application)

Kompri, Manajemen dan Kepemimpinan Pondok Pesantren, 2016, Jakarta: Prenadamedia Grup

Lubis. Yusniar, etc, Manajemen dan Riset Sumber Daya Manusia, (Bandung: Alfabeta, 2018)

Priyono, Manajemen Sumber Daya Manusia, (Sidoarjo: Zifatama Publisher, 2010)

https://www.binadarma.ac.i 
Qodir. Abdullah, Manajemen Sumber Daya Manusia di Pondok Pesantren Alfalah Bakalan

Kecamatan

Kalinyamatan

Kabupaten Jepara, JMP

Volume 1 nomor 2, December 2012

Qomar. Mujamil, Pesantren; dari Transformasi Metodoloi Menuju Demokratisasi Institusi, Jakarta: Penerbit Erlangga,

Sedarmayanti,

Manajemen

Daya

2010, Sumber

Reformasi Birokrasi dan Manajemen Pegawai Negeri Sipil, Bandung: Refika Aditama

Shaun Tyson, 2006, Essentials of Human Resource Management, fith edition, USA: Elsevier

Shin. Yoo Keun, Human Resource Management in Korean Firms and Its Future Outlook, Seoul Nastional University: Seoul Journal of Business, Volume 5, Number 1/5, December 1999
Smt. Shyamala. M., Modul of Human Resource Management, (University of Calicut, Department of Commerce and Management Studies)

Sutrisno. Edy, Manajemen Sumber Daya Manusia, (Jakarta: Kencana, 2017)

Taufiqurokhman, Mengenal Sumber Daya Manusia, (Fakultas Ilmu Sosial dan Politik Universitas Prof. Dr. Moestopo Beragama, 2009)

Zuhimma, Dinamika Perkembangan Pondok Pesantren di Indonesia, Jurnal Darul 'Ilmi Vol. 01, No. 02, 2013 